\title{
Influence of Bacterial Competitors on Salmonella enterica and Enterohemorrhagic Escherichia coli Growth in Microbiological Media and Attachment to Vegetable Seeds
}

\author{
Da Liu ${ }^{1}$, Ronald Walcott ${ }^{2}$, Kevin Mis Solval ${ }^{1} \mathbb{D}$ and Jinru Chen ${ }^{1, *}$ \\ 1 Department of Food Science and Technology, The University of Georgia, Griffin, GA 30602, USA; \\ dliu@uga.edu (D.L.); kmissolval@uga.edu (K.M.S.) \\ 2 Department of Plant Pathology, The University of Georgia, Athens, GA 30602, USA; rwalcott@uga.edu \\ * Correspondence: jchen@uga.edu; Tel.: +1-770-412-4738
}

Citation: Liu, D.; Walcott, R.; Mis

Solval, K.; Chen, J. Influence of

Bacterial Competitors on Salmonella enterica and Enterohemorrhagic

Escherichia coli Growth in

Microbiological Media and

Attachment to Vegetable Seeds. Foods 2021, 10, 285. https://doi.org/ $10.3390 /$ foods 10020285

Received: 16 December 2020

Accepted: 26 January 2021

Published: 31 January 2021

Publisher's Note: MDPI stays neutral with regard to jurisdictional claims in published maps and institutional affiliations.

Copyright: (C) 2021 by the authors. Licensee MDPI, Basel, Switzerland. This article is an open access article distributed under the terms and conditions of the Creative Commons Attribution (CC BY) license (https:// creativecommons.org/licenses/by/ $4.0 /)$
Abstract: Interests in using biological agents for control of human pathogens on vegetable seeds are rising. This study evaluated whether probiotic bacterium Lactobacillus rhamnosus GG, bacterial strains previously used as biocontrol agents in plant science, as well as a selected plant pathogen could compete with foodborne human pathogens, such as Salmonella enterica and enterohemorrhagic Escherichia coli (EHEC), for growth in microbiological media and attachment to vegetable seeds; and to determine whether the metabolites in cell-free supernatants of competitive bacterial spent cultures could inhibit the growth of the two pathogens. The results suggest that the co-presence of competitive bacteria, especially L. rhamnosus GG, significantly $(p<0.05)$ inhibited the growth of Salmonella and EHEC. Cell-free supernatants of L. rhamnosus GG cultures significantly reduced the pathogen populations in microbiological media. Although not as effective as L. rhamnosus GG in inhibiting the growth of Salmonella and EHEC, the biocontrol agents were more effective in competing for attachment to vegetable seeds. The study observed the inhibition of human bacterial pathogens by competitive bacteria or their metabolites and the competitive attachment to sprout seeds among all bacteria involved. The results will help strategize interventions to produce vegetable seeds and seed sprouts free of foodborne pathogens.

Keywords: Salmonella; EHEC; vegetable seeds; biological control; bacterial attachment; growth inhibition

\section{Introduction}

Consumption of raw and lightly cooked sprouts have been linked to multiple highprofile outbreaks of human gastrointestinal infections [1-3]. The most likely source of pathogens in sprout-associated outbreaks is contaminated seeds [4]. Pathogens such as Salmonella and E. coli O157:H7, when present on seeds, can grow rapidly from a low contamination level of ca. $0.1 \mathrm{log} \mathrm{CFU} / \mathrm{g}$ to as high as $10^{6} \mathrm{log}$ units under sprouting conditions [5]. Although seeds are not generally regarded as a contamination source of fresh produce other than sprouts, recent research by Deering et al. [6] reported the presence of E. coli O157:H7 in mature tomato fruits grown from seeds contaminated with the pathogen. Therefore, the sanitary condition of seeds needs to be addressed in a great effort to reduce the growing incidence of foodborne outbreaks associated with fresh produce.

Hypochlorite-based sanitizers have been recommended by the U.S. Food and Drug Administration to inactivate Salmonella and enterohemorrhagic Escherichia coli (EHEC) on vegetable seeds at the postharvest stage $[7,8]$. In general, a 3-log population reduction can be reached by applying the sanitizer on sprout seeds for $10 \mathrm{~min}$ [9]. However, these pathogens cannot be reliably eliminated due to bacterial strain-specific resistance to chlorine and/or the internalization of pathogen cells into the protected niches of vegetable seeds $[10,11]$. 
The potential of using antagonistic microorganisms as control agents on harvested vegetable seeds has been discussed [12,13]. Inoculation of Acidovorax avenae subsp. Avenae on watermelon seeds before planting could reduce the transmission of bacterial fruit blotch of cucurbits caused by Acidovorax avenae subsp. citrulli by $96.5 \%$ [14]. Treating alfalfa seeds with Pseudomonas strain 2-79 has been reported to reduce the population of Salmonella by 1-2 log units during sprouting [15]. An advantage of using biocontrol agents over chemical/physical disinfection for pathogen control is that once the microorganisms used as biocontrol agents establish a population on vegetable seeds/plants, sustainable protection can be obtained throughout the sprouting/cultivation process [16].

The mechanisms of utilizing biocontrol agents to improve the microbial safety of vegetable seeds include growth competition, via accessing available nutrients between plant/human pathogens and the microorganisms used as biocontrol agents, and the inhibitory effects of antagonistic metabolites, produced by biocontrol agents towards plant/human pathogens [17]. For instance, the preemptive colonization of orange flowers by Pseudomonas fluorescens A506 can effectively prevent future Erwinia amylovora infections [18]. Active production of lactic acid and bacteriocin by Lactobacillus spp. has led to its application as Salmonella-control agents on meat products [19]. Beyond that, metabolites such as fatty acids and biosurfactants produced by Bacillus spp. have been reported to reduce adhesion and biofilm formation by human pathogen cells on food contact surfaces [20].

The objectives of this study were to observe whether a probiotic bacterium, strains of bacteria previously used as biocontrol agents in plant science, as well as a selected plant pathogen could compete with foodborne human pathogens such as Salmonella and EHEC for growth in microbiological media and attachment to vegetable seeds, and to determine whether the metabolites in cell-free supernatants of spent cultures of competitive bacteria could significantly inhibit the growth of Salmonella and EHEC under laboratory conditions.

\section{Materials and Methods}

\subsection{Bacterial Strains and Vegetable Seeds}

Four S. enterica, three E. coli O157:H7, and one E. coli O104:H4 strain were used in the study due to their previous association with sprout- or fresh produce-associated outbreaks of infections (Table 1). Cells of each pathogen strain resistant to nalidixic acid (NA) were selected on tryptic soy agar (TSA) containing $50 \mu \mathrm{g} / \mathrm{mL}$ of NA (NATSA). The NA resistant derivates were confirmed in a comparative preliminary study as appropriate surrogates of the wildtype parental strains. Three bacterial strains previously used as biological control agents including P. fluorescens A506, Bacillus mojavensis RRC 101, and B. subtilis ATCC 6051 were from the culture collection of Dr. Ronald Walcott (Table 1). A well-characterized probiotic strain, Lactobacillus rhamnosus GG was obtained from a commercial source (Culturelle ${ }^{\circledR}$, i-Health Inc., Cromwell, CT, USA). A plant pathogen, Pseudomonas syringae pv. Tomato DC3000 (Pst DC3000), was also included to observe its possible interactions with the human pathogenic bacterial strains used in the study. All bacterial cultures were maintained at $-80{ }^{\circ} \mathrm{C}$ until use. The microbiological media used were from Becton, Dickinson, and Company (Sparks, MD, USA) unless specified.

Seeds of alfalfa (Medicago sativa), fenugreek (Trigonella foenum-graecum), lettuce (Lactuca sativa 'Iceberg'), and tomato (Solanum lycopersicum 'Roma') were included in the study. These seeds or the fresh produce developed from them had a previous link to the outbreaks of human gastrointestinal infections. The seeds were purchased from Twilley Seed Company (Hodges, SC, USA) and stored at $10^{\circ} \mathrm{C}$ until use. 
Table 1. Bacterial strains used in this study.

\begin{tabular}{|c|c|c|}
\hline Nalidixic Acid Resistant Derivate & Serovar/Strain & Source \\
\hline Salmonella enterica & $\begin{array}{l}\text { Stanley } \\
\text { Baildon } \\
\text { Montevideo } \\
\text { Cubana }\end{array}$ & $\begin{array}{c}\text { Sprout-related outbreak, Finland, Canada, and the US, } 1997 \\
\text { Tomato- and lettuce-related outbreaks, the US, } 1999 \\
\text { Tomato-related outbreak, the US, } 1993 \\
\text { Sprout-related outbreak, the US, } 2012\end{array}$ \\
\hline Enterohemorrhagic Escherichia coli & $\begin{array}{l}\text { F4546 } \\
\text { BAA-2326 } \\
\text { K4492 } \\
\text { H1730 }\end{array}$ & $\begin{array}{c}\text { Sprout-related outbreak, the US, } 1997 \\
\text { Fenugreek sprout-related outbreak, Germany, } 2011 \\
\text { Spinach-related outbreak, the US, } 2006 \\
\text { Lettuce-related outbreak, the US, } 2003\end{array}$ \\
\hline Pseudomonas fluorescenes & A506 & $\begin{array}{l}\text { Commercial biocontrol agent for Erwinia amylovora (fire } \\
\text { blight) on fruits }\end{array}$ \\
\hline Bacillus mojavensis & RRC 101 & $\begin{array}{l}\text { Commercial biocontrol agent for Fusarium verticillioides in } \\
\text { maize and other crops; surfactin-producing }\end{array}$ \\
\hline Bacillus subtilis & ATCC 6051 & surfactin-producing strain \\
\hline Lactobacillus rhamnosus & GG & Commercial probiotic \\
\hline Pseudomonas syringae pv. tomato & DC 3000 & Frequent seed-borne pathogen on tomato plant \\
\hline
\end{tabular}

2.2. Competitive Growth between Salmonella or EHEC and Selected Plant Pathogen, Probiotic Strain, or Biocontrol Agents in Microbiological Media

A previously described [21], 1:1 (v/v) mixture of De Man, Rogosa and Sharpe (MRS) broth and tryptic soy broth (TSB) (M/T broth) was used in this portion of the study to minimize the influence of microbiological media on the growth of L. rhamnosus GG vs. other bacterial strains. Fresh M/T broth was prepared by aseptically mixing an equal volume of pre-autoclaved MRS broth and TSB before use. Individual cultures of Salmonella and EHEC strains were grown at $37^{\circ} \mathrm{C}$ and those of the biocontrol agents/plant pathogen at $25^{\circ} \mathrm{C}$, all in $10 \mathrm{~mL} \mathrm{M} / \mathrm{T}$ broth for $18 \mathrm{~h}$.

The competitive growth study was performed according to a previously described protocol [21] with modifications. A Salmonella or EHEC overnight culture $(1.0 \mathrm{~mL})$, prediluted to ca. $3.0 \log \mathrm{CFU} / \mathrm{mL}$ with $\mathrm{M} / \mathrm{T}$ broth, was mixed, respectively with $1.0 \mathrm{~mL}$ of the overnight culture of P. fluorescens A506, B. mojavensis RRC 101, B. subtilis ATCC 6051, L. rhamnosus GG, and their cocktails, as well as plant pathogen Pst DC3000, all pre-diluted to ca. $5.0 \log \mathrm{CFU} / \mathrm{mL}$ with M/T broth. One of the cocktails (Cocktail 1) had an equal number of B. subtilis ATCC6051, B. mojavensis RRC101, and P. fluorescens A506 cells; whereas the other cocktail (Cocktail 2) contained an equal population of the same three bacterial strains plus L. rhamnosus GG. The cocktails were vortexed vigorously to ensure uniformity. The mixed cultures of human pathogens and their competitors were incubated at $25^{\circ} \mathrm{C}$ with agitation at $100 \mathrm{rpm}$ on a platform shaker (Orbit Shaker, Lab-Line Instruments, Inc., Lumberton, NC, USA). A separate set of tissue culture plates holding the mixture of L. rhamnousus GG and each Salmonella/E. coli strain was prepared in the same manner except that the incubation temperature was set to $37^{\circ} \mathrm{C}$ since L. rhamnousus GG, unlike other competitive bacterial strains used in the study, has optimal growth at this temperature. The control samples were prepared by mixing $1 \mathrm{~mL}$ overnight culture of each S. enterica and EHEC strain pre-diluted to ca. $3 \log$ CFU/mL in M/T broth with $1 \mathrm{~mL}$ of $\mathrm{M} / \mathrm{T}$ broth for incubation at both 37 and $25^{\circ} \mathrm{C}$. Broth culture samples were collected after $6,12,24,48$, and $72 \mathrm{~h}$ of the incubation at the set temperature, and the collected samples were diluted in phosphate-buffered saline (PBS; pH 7.4), and appropriate dilutions were plated in duplicate on XLT4 or sorbitol MacConkey agar supplemented with $50 \mu \mathrm{g} / \mathrm{mL}$ NA (NASMAC). Colonies of S. enterica, E. coli O157:H7, and E. coli O104:H4 were counted after $24-48 \mathrm{~h}$ of incubation at $37^{\circ} \mathrm{C}$. 


\subsection{Competitive Attachment between Salmonella or EHEC and Selected Plant Pathogen, Probiotic Strain, or Biocontrol Agents to Vegetable Seeds}

Competitive attachment between Salmonella or EHEC cells and those of selected plant pathogen, probiotic strain, and biocontrol agents to vegetable seeds was studied using a previously published protocol [22] with modifications. Two grams of each type of vegetable seeds described above were placed in $50-\mathrm{mL}$ centrifuge tubes (Fisher Scientific, Asheville, NC, USA) and sanitized with $10 \mathrm{~mL}$ of $20,000 \mathrm{ppm}$ sodium hypochlorite solution ( $\mathrm{pH}$ 6.8; $\mathrm{BD}$ ) at room temperature for $10 \mathrm{~min}$ with gentle mixing. The sanitizer solution was then decanted, and residual chlorine was removed by soaking the seeds in $10 \mathrm{~mL}$ Dey-Engley neutralizing broth (BD) for $10 \mathrm{~min}$ and rinsing twice, each with $10 \mathrm{~mL}$ of sterilized deionized water.

Salmonella or EHEC cultures were grown in M/T broth at $37^{\circ} \mathrm{C}$, while individual competitive bacterial cultures were grown in the same broth at $25^{\circ} \mathrm{C}$ till the cell concentrations of each culture reached ca. $10^{9} \mathrm{CFU} / \mathrm{mL}$. An equal volume of the four Salmonella or EHEC cultures were mixed and then diluted in PBS to create two 4-strain pathogen cocktails having a cell population of ca. $10^{4} \mathrm{CFU} / \mathrm{mL}$. Individual or mixed competitive bacterial cultures were also diluted to $10^{4} \mathrm{CFU} / \mathrm{mL}$ in PBS. All samples were mixed vigorously using a vortex device to ascertain that cells were evenly distributed.

Ten milliliters of the Salmonella or EHEC cocktail was mixed with an equal volume of each competitive strain/mixture in Falcon centrifuge tubes containing sanitized vegetable seeds. Ten milliliters of each Salmonella or EHEC cocktail and $10 \mathrm{~mL}$ of PBS were added to a separate set of seeds as controls. The precise inoculation levels were determined by plating $0.1 \mathrm{~mL}$ of appropriately diluted cell suspensions on TSA or NATSA. Vegetable seeds in the centrifuge tubes were agitated horizontally at $100 \mathrm{rpm}$ in an orbital platform shaker at $20^{\circ} \mathrm{C}$ for $5 \mathrm{~h}$. The inoculums were then decanted, and the seeds were rinsed twice, each with $10 \mathrm{~mL}$ sterile water for $1 \mathrm{~min}$ with gentle mixing. Seeds were then soaked overnight at $4{ }^{\circ} \mathrm{C}$ in $5 \mathrm{~mL}$ of PBS to release attached bacterial cells. On the next day, seed samples were vortexed at maximal speed (3200 rpm) (Fisher Scientific) for $50 \mathrm{~s}$ before $0.1 \mathrm{~mL}$ of soaking solution was spread plated on XLT4 or NASMAC plates in duplicate. The plates were incubated at $37^{\circ} \mathrm{C}$ for $24-48 \mathrm{~h}$ for the enumeration of Salmonella and E. coli colonies. The percentage of attached cells in the total number of cells used in the experiment was used to express the ability of each pathogen cocktail in attaching to the vegetable seeds as affected by the presence of bacterial competitors.

\subsection{Effect of Metabolites in Cell-Free Supernatants (CFS) of the Spend Cultures of Biocontrol Agents and Probiotic Strain on Salmonella and EHEC}

For the preparation of cell-free supernatants, L. rhamnosus GG was grown in $10 \mathrm{~mL}$ MRS broth at $37^{\circ} \mathrm{C}$ for $72 \mathrm{~h}$. Each biological control agent was grown individually in $10 \mathrm{~mL}$ TSB at $25^{\circ} \mathrm{C}$ for $72 \mathrm{~h}$. Obtained bacterial cultures were centrifuged at $6,000 \times g$ for $10 \mathrm{~min}$. The resulting supernatants of the bacterial cultures were carefully removed. Suspending bacterial cells in the supernatants were removed by filtration using $0.45-\mu \mathrm{m}$ sterile syringe filters (Fischer Scientific, Hampton, NH, USA). A one-milliliter aliquot of each filtered supernatant was mixed with $1 \mathrm{~mL}$ of an overnight culture of each Salmonella and E. coli strain, pre-diluted to ca. $10^{5} \mathrm{CFU} / \mathrm{mL}$ with PBS. The pathogens cells in the supernatants of competitive bacterial spent cultures were incubated at $25^{\circ} \mathrm{C}$, and samples were collected after $2,4,8,12,24$, and $48 \mathrm{~h}$ during incubation. Collected samples $(0.1 \mathrm{~mL})$ were plated in duplicate on XLT4 or NCSMAC agar plates, and colonies of Salmonella and EHEC were counted after incubation at $37^{\circ} \mathrm{C}$ for $24-48 \mathrm{~h}$. 


\subsection{Statistical Analysis}

Every sample in the experiment has a duplicate, and each experiment was conducted in triplicates. The mean populations of different Salmonella and EHEC strains as affected by (1) the presence of different competitive agents or their cell-free metabolites, (2) different pathogen strains used, and (3) sampling times were arranged into the general linear model of the SAS software (Version 4, SAS Institute, Cary, NC, USA). Fisher's Least Significance Difference test was used to separate the means. The same statistical protocol was also used to compare the percentage of attachment of Salmonella and EHEC cells to alfalfa, fenugreek, lettuce, and tomato seeds. Type III error test was performed to determine the significance of each variable and interaction between or among different variables. For all comparisons, $p$-value less than 0.05 was considered significant.

\section{Results}

\subsection{Competitive Growth between Salmonella/EHEC and Bacterial Competitors}

Overall mean populations of all four Salmonella or EHEC strains in co-cultures with individual competitive bacterial strains/cocktails are shown in Table 2. The mean populations of both Salmonella and EHEC in the co-cultures were significantly lower $(p<0.05)$ than those in the control samples. However, the margins of differences were sometimes small; Salmonella and EHEC population differences in co-cultures with competitive bacterial strains other than L. rhamnousus GG were all below $1 \log$ unit. Among the three tested biocontrol agents, Salmonella and EHEC populations in co-culture with P. fluorescens A506 were the lowest. EHEC or Salmonella populations in co-culturing with B. mojavensis RRC 101 were similar to those with B. subtilis ATCC 6051. The presence of plant-pathogen, Pst DC3000 in co-cultures also slightly retarded the growth of Salmonella and EHEC during the 72-h co-incubation period.

Table 2. Overall mean S. enterica and EHEC populations in co-cultures with different competitive bacterial strains and at different sampling points.

\begin{tabular}{|c|c|c|c|c|}
\hline \multirow[t]{2}{*}{ Main Effect } & \multicolumn{2}{|c|}{$\begin{array}{c}\text { Mean Population of } \\
\text { Salmonella or EHEC (log } \\
\text { CFU/mL) as Influenced by }\end{array}$} & \multirow[t]{2}{*}{ Main Effect } & \multirow{2}{*}{$\begin{array}{l}\text { Mean Population (log } \\
\text { CFU/mL) of Salmonella } \\
\text { and EHEC as } \\
\text { Influenced by }\end{array}$} \\
\hline & $\begin{array}{l}\text { S. enterica }{ }^{1} \\
\quad(n=540)\end{array}$ & $\begin{array}{l}\text { E. } \text { coli }^{2} \\
(n=540)\end{array}$ & & \\
\hline Competitive bacteria presence & & & S. enterica strains used & \\
\hline Control $(n=60)$ & $7.8 \pm 0.26 \mathrm{~A}$ & $8.1 \pm 0.26 \mathrm{~A}$ & S. Montevideo $(n=135)$ & $6.8 \pm 0.19 \mathrm{~A}$ \\
\hline P. syringae pv. tomato DC $3000(n=60)$ & $7.4 \pm 0.24 \mathrm{~B}$ & $7.8 \pm 0.26 \mathrm{~B}$ & S. Baildon $(n=135)$ & $6.6 \pm 0.19 \mathrm{~A}$ \\
\hline B. subtilis ATCC $6051(n=60)$ & $7.3 \pm 0.22 \mathrm{BC}$ & $7.6 \pm 0.25 \mathrm{C}$ & S. Stanley $(n=135)$ & $6.1 \pm 0.20 \mathrm{~B}$ \\
\hline B. mojavensis RRC $101(n=60)$ & $7.2 \pm 0.21 \mathrm{C}$ & $7.5 \pm 0.24 \mathrm{C}$ & S. Cubana $(n=135)$ & $6.1 \pm 0.19 \mathrm{~B}$ \\
\hline P. fluorescenes A506 $(n=60)$ & $7.0 \pm 0.22 \mathrm{D}$ & $7.4 \pm 0.24 \mathrm{D}$ & E. coli strains used & \\
\hline Cocktail $1^{3}(n=60)$ & $6.9 \pm 0.24 \mathrm{D}$ & $7.3 \pm 0.24 \mathrm{D}$ & E. coli $\mathrm{H} 1730(n=135)$ & $7.9 \pm 0.12 \mathrm{~A}$ \\
\hline Cocktail $2^{4}(n=60)$ & $6.9 \pm 0.24 \mathrm{D}$ & $7.2 \pm 0.24 \mathrm{E}$ & E. coli $\mathrm{K} 4492(n=135)$ & $7.7 \pm 0.13 \mathrm{~A}$ \\
\hline L. rhamnosus GG $\left(25^{\circ} \mathrm{C} ; n=60\right)$ & $6.0 \pm 0.23 \mathrm{E}$ & $6.8 \pm 0.22 \mathrm{~F}$ & E. coli $\mathrm{F} 4546(n=135)$ & $7.1 \pm 0.17 \mathrm{~B}$ \\
\hline L. rhamnosus GG $\left(37^{\circ} \mathrm{C} ; n=60\right)$ & $2.5 \pm 0.31 \mathrm{~F}$ & $6.6 \pm 0.15 \mathrm{G}$ & E. coli BAA $2326(n=135)$ & $6.4 \pm 0.17 \mathrm{C}$ \\
\hline \multicolumn{5}{|l|}{ Sampling points $(\mathrm{h})$ used } \\
\hline $24(n=108)$ & $7.5 \pm 0.15 \mathrm{~A}$ & $8.7 \pm 0.07 \mathrm{~B}$ & & \\
\hline $48(n=108)$ & $7.5 \pm 0.23 \mathrm{~A}$ & $9.0 \pm 0.06 \mathrm{~A}$ & & \\
\hline $72(n=108)$ & $6.9 \pm 0.26 \mathrm{~B}$ & $8.4 \pm 0.10 \mathrm{C}$ & & \\
\hline $12(n=108)$ & $6.2 \pm 0.12 \mathrm{C}$ & $6.3 \pm 0.14 \mathrm{D}$ & & \\
\hline $6(n=108)$ & $3.8 \pm 0.24 \mathrm{D}$ & $4.1 \pm 0.11 \mathrm{E}$ & & \\
\hline
\end{tabular}

\footnotetext{
${ }^{1}$ Mean populations of $S$. enterica within the same variable in a column not followed by the same letter are significantly different $(p<0.05)$

2 Mean populations of $E$. coli within the same comparable in a column not followed by the same letter are significantly different $(p<0.05$ ).

3 A mixed culture of P. fluorescenes AS06, B. mojavensis RRC 101 and B. subtilis ATCC 6051. ${ }^{4}$ A mixed culture of P. fluorescenes AS06,

B. mojavensis RRC 101, B. subtilis ATCC 6051 and L. rhamnosus GG.
}

The Salmonella populations in the co-culture with L. rhamnousus GG were significantly lower than those in other co-cultures, at both $37^{\circ} \mathrm{C}$ and $25{ }^{\circ} \mathrm{C}$ (Table 2). The mean population of Salmonella in co-culture with L. rhamnousus GG at $37^{\circ} \mathrm{C}$ was $5.3 \log$ units lower than the population in the control and 1.8 log lower than the Salmonella population 
in the co-culture grown at $25^{\circ} \mathrm{C}$. Adding L. rhamnousus GG to Cocktail 1 did not result in a greater $(p>0.05)$ impact on Salmonella growth, but a different result was observed with EHEC over the 72-h co-incubation period. Mean Salmonella and EHEC populations in the co-culturing with Cocktail 2 were significantly higher than those with L. rhamnousus GG at both $25^{\circ} \mathrm{C}$ and $37^{\circ} \mathrm{C}$. The populations of EHEC were significantly lower when they were co-cultured with Cocktail 2 compared to the co-cultures with individual competitive bacterial strains. Mean Salmonella populations were similar in the co-cultures with the two cocktails and $P$. fluorescens A506, and the three populations were significantly lower than those in the co-cultures with B. mojavensis RRC 101, B. subtilis ATCC 6051, and Pst DC3000.

When co-cultured with their growth competitors, the mean populations of $S$. Cubana and $S$. Stanley were significantly lower $(p<0.05)$ than those of $S$. Montevideo and $S$. Baildon (Table 2). E. coli H1730 and K4492 populations were significantly higher than the mean populations of E. coli F4546 and BAA 2326. A significant increase in the mean populations of Salmonella and EHEC was seen at most sampling points except the Salmonella population at the 24 and $48 \mathrm{~h}$ sampling points.

Different from the results of overall statistical analysis shown in Table 2, no significant difference was observed among the populations of the four individual Salmonella strains recovered from the co-cultures with different bacterial competitors at $25^{\circ} \mathrm{C}$ (Table 3), except co-incubation with L. rhamnosus GG. Furthermore, all four Salmonella strains had similar mean cell populations in the co-cultures with the same growth competitors. Different observations were made with EHEC, and co-culture with L. rhamnosus GG only significantly reduced the population of H1730 and K4492 (Table 4). The mean populations of E. coli BAA2326 were the lowest among all EHEC cultures.

According to the results in Figure 1a, the mean populations of Salmonella in the control and co-cultures with each competitive bacterium increased exponentially within the first $24 \mathrm{~h}$ of incubation at $25^{\circ} \mathrm{C}$ before entering the stationary growth phase. The population difference between the controls and co-cultures with individual bacterial strains was from 0.9 to $1.3 \log$ units at the $24 \mathrm{~h}$ sampling point. No significant improvement in Salmonella inhibition was observed at the 48-h sampling point. At the 72-h sampling point, however, the mean Salmonella population in the co-culture with L. rhamnosus GG was 4.5 log units lower than the control. Salmonella population differences among other co-cultures ranged from 0.5 to $1.4 \log$ units at this sampling point.

Compared to the control, the mean populations of all four tested EHEC strains were 0.7-2.9 log units lower when co-incubated with the bacterial competitors throughout the 72$\mathrm{h}$ incubation period at $25^{\circ} \mathrm{C}$ (Figure $1 \mathrm{~b}$ ). At the 72-h sampling point, the EHEC population was $1.4 \log \mathrm{CFU} / \mathrm{mL}$ lower in the co-cultures with Cocktail 1,1.3 log CFU/mL lower in co-culture with Cocktail 2, and $2.8 \log$ CFU/mL lower in co-culture with L. rhamnosus GG than the population in the control culture. Similar to what was observed with Salmonella, a significant decrease in the EHEC population was observed between 48 and $72 \mathrm{~h}$ in coculture with L. rhamnosus GG, but the level of population decrease was less profound compared to that of Salmonella (Figure 1a).

The competitiveness of L. rhamnosus GG towards Salmonella and EHEC growth was much stronger at $37^{\circ} \mathrm{C}$ compared to $25^{\circ} \mathrm{C}$ (Figure 2). After $24 \mathrm{~h}$ of co-incubation with $L$. rhamnosus GG, the mean populations of all four tested Salmonella or EHEC strains were lower at $37^{\circ} \mathrm{C}$ than at $25^{\circ} \mathrm{C}$. No Salmonella cells were detected from the co-culture with $L$. rhamnosus GG at $37^{\circ} \mathrm{C}$ after the 48-h sampling point (detection limit: $10 \mathrm{CFU} / \mathrm{mL}$ ). The mean populations of EHEC recovered from the co-cultures with L. rhamnosus GG were relatively higher than those of Salmonella incubated at the same temperatures. 
Table 3. Mean populations of individual Salmonella strains in co-cultures with different competitive bacterial strains and the plant pathogen at $25^{\circ} \mathrm{C}$.

\begin{tabular}{|c|c|c|c|c|c|c|c|c|}
\hline \multirow{2}{*}{ Salmonella Strains } & \multicolumn{8}{|c|}{$\begin{array}{l}\text { Mean Population of Salmonella }{ }^{1} \\
\quad(\log \text { CFU } / \mathrm{mL})(n=480)\end{array}$} \\
\hline & $\begin{array}{c}\text { P. fluorescens } \\
\text { A506 }\end{array}$ & Cocktail 2 & Cocktail 1 & L. rhamnosus GG & Pst DC3000 & $\begin{array}{l}\text { B. mojavensis } \\
\text { RRC101 }\end{array}$ & Control & $\begin{array}{l}\text { B. subtilis } \\
\text { ATCC6051 }\end{array}$ \\
\hline Montevideo $(n=15)$ & $7.6 \pm 0.39 \mathrm{aAB}$ & $7.4 \pm 0.44 \mathrm{aAB}$ & $7.3 \pm 0.44 \mathrm{aAB}$ & $6.5 \pm 0.39 \mathrm{aB}$ & $7.8 \pm 0.45 \mathrm{aA}$ & $7.6 \pm 0.40 \mathrm{aAB}$ & $8.0 \pm 0.55 \mathrm{aA}$ & $7.6 \pm 0.41 \mathrm{aAB}$ \\
\hline Baildon $(n=15)$ & $7.2 \pm 0.45 \mathrm{aA}$ & $7.2 \pm 0.46 \mathrm{aA}$ & $7.4 \pm 0.46 \mathrm{aA}$ & $5.9 \pm 0.53 \mathrm{aB}$ & $7.8 \pm 0.41 \mathrm{aA}$ & $7.4 \pm 0.39 \mathrm{aA}$ & $8.0 \pm 0.49 \mathrm{aA}$ & $7.6 \pm 0.38 \mathrm{aA}$ \\
\hline Stanley $(n=15)$ & $6.8 \pm 0.47 \mathrm{aAB}$ & $6.3 \pm 0.46 \mathrm{aAB}$ & $6.5 \pm 0.48 \mathrm{aAB}$ & $5.7 \pm 0.47 \mathrm{aB}$ & $7.2 \pm 0.46 \mathrm{aA}$ & $7.0 \pm 0.45 \mathrm{aAB}$ & $7.5 \pm 0.56 \mathrm{aA}$ & $7.0 \pm 0.49 \mathrm{aAB}$ \\
\hline Cubana $(n=15)$ & $6.5 \pm 0.46 \mathrm{aAB}$ & $6.5 \pm 0.54 \mathrm{aAB}$ & $6.5 \pm 0.45 \mathrm{aAB}$ & $5.9 \pm 0.49 \mathrm{aB}$ & $6.8 \pm 0.54 \mathrm{aAB}$ & $6.8 \pm 0.45 \mathrm{aAB}$ & $7.9 \pm 0.50 \mathrm{aA}$ & $6.8 \pm 0.47 \mathrm{aAB}$ \\
\hline
\end{tabular}

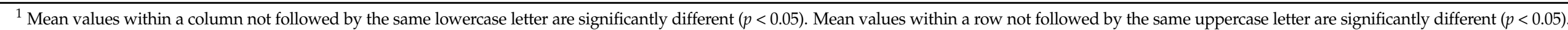

Table 4. Mean populations of individual EHEC strains in co-cultures with different competitive bacterial strains and the plant pathogen at $25^{\circ} \mathrm{C}$.

\begin{tabular}{|c|c|c|c|c|c|c|c|c|}
\hline \multirow[t]{2}{*}{ EHEC Strains } & \multicolumn{8}{|c|}{$\begin{array}{l}\text { Mean Population of EHEC } \\
\quad(\log \text { CFU } / \mathrm{mL})(n=480)\end{array}$} \\
\hline & $\begin{array}{l}\text { P. fluorescens } \\
\text { A506 }\end{array}$ & Cocktail 2 & Cocktail 1 & L. rhamnosus GG & Pst DC3000 & $\begin{array}{l}\text { B. mojavensis } \\
\text { RRC101 }\end{array}$ & Control & $\begin{array}{l}\text { B. subtilis } \\
\text { ATCC6051 }\end{array}$ \\
\hline $\mathrm{H} 1730(n=15)$ & $8.2 \pm 0.30 \mathrm{aAB}$ & $7.5 \pm 0.35 \mathrm{abAB}$ & $7.7 \pm 0.35 \mathrm{abAB}$ & $7.4 \pm 0.38 \mathrm{aB}$ & $8.6 \pm 0.33 \mathrm{aAB}$ & $8.2 \pm 0.33 \mathrm{aAB}$ & $8.6 \pm 0.42 \mathrm{abA}$ & $8.3 \pm 0.32 \mathrm{aAB}$ \\
\hline $\mathrm{K} 4492(n=15)$ & $8.1 \pm 0.40 \mathrm{aAB}$ & $7.6 \pm 0.43 \mathrm{aAB}$ & $7.7 \pm 0.42 \mathrm{aAB}$ & $7.1 \pm 0.46 \mathrm{aB}$ & $8.4 \pm 0.38 \mathrm{aA}$ & $8.3 \pm 0.38 \mathrm{aA}$ & $8.7 \pm 0.41 \mathrm{aA}$ & $8.3 \pm 0.39 \mathrm{aA}$ \\
\hline $\mathrm{F} 4546(n=15)$ & $6.9 \pm 0.56 \mathrm{abA}$ & $7.3 \pm 0.58 \mathrm{abA}$ & $7.3 \pm 0.56 \mathrm{abA}$ & $6.7 \pm 0.47 \mathrm{aA}$ & $7.7 \pm 0.52 \mathrm{abA}$ & $7.3 \pm 0.53 \mathrm{abA}$ & $7.9 \pm 0.52 \mathrm{abA}$ & $7.2 \pm 0.54 \mathrm{abA}$ \\
\hline BAA2326 $(n=15)$ & $6.3 \pm 0.48 \mathrm{bA}$ & $6.2 \pm 0.53 \mathrm{bA}$ & $6.6 \pm 0.49 \mathrm{bA}$ & $6.0 \pm 0.43 \mathrm{aA}$ & $6.6 \pm 0.60 \mathrm{bA}$ & $6.7 \pm 0.57 \mathrm{bA}$ & $7.3 \pm 0.65 \mathrm{bA}$ & $6.6 \pm 0.59 \mathrm{bA}$ \\
\hline
\end{tabular}

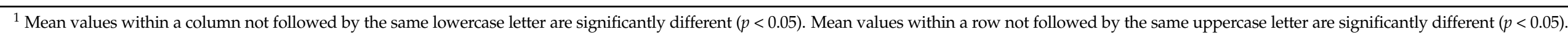




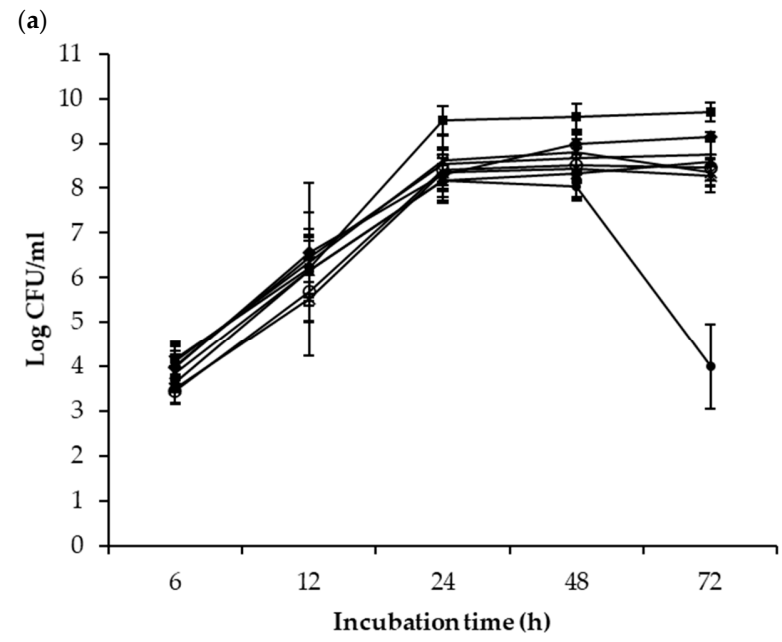

(b)

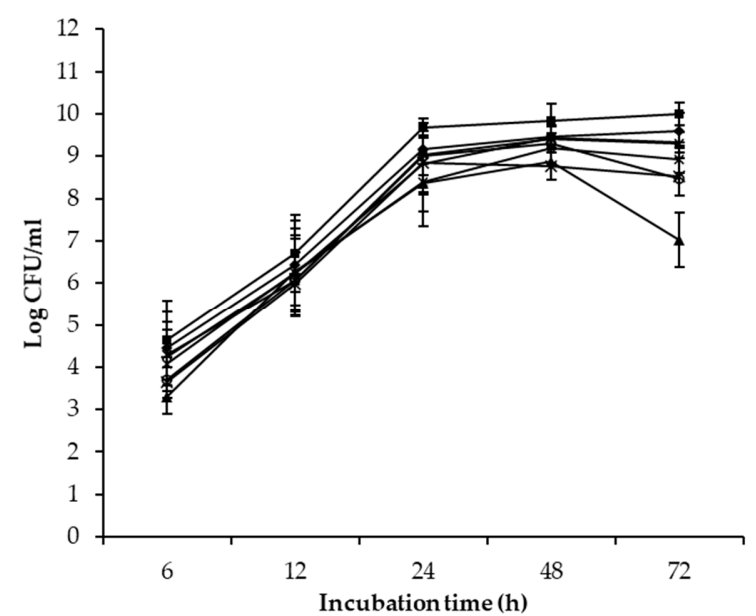

Figure 1. Mean populations of all four strains of S. enterica (a) or E. coli (b) in the controls (-) and the mixed cultures with P. fluorescenes A506 ( $\nleftarrow$ ), B. subtilis ATCC $6051(\leftarrow)$ ), B. mojavensis RRC $101(\longrightarrow$ ), Cocktail $1(-\bullet$ ), Cocktail $2(\rightarrow$ ) , L. rhamnousus GG $(\longrightarrow-)$ ) and P. syringae pv. tomato DC3000 ( - $\bullet$ ) after $6,12,24,48$ and $72 \mathrm{~h}$ of co-incubation at $25^{\circ} \mathrm{C}$.

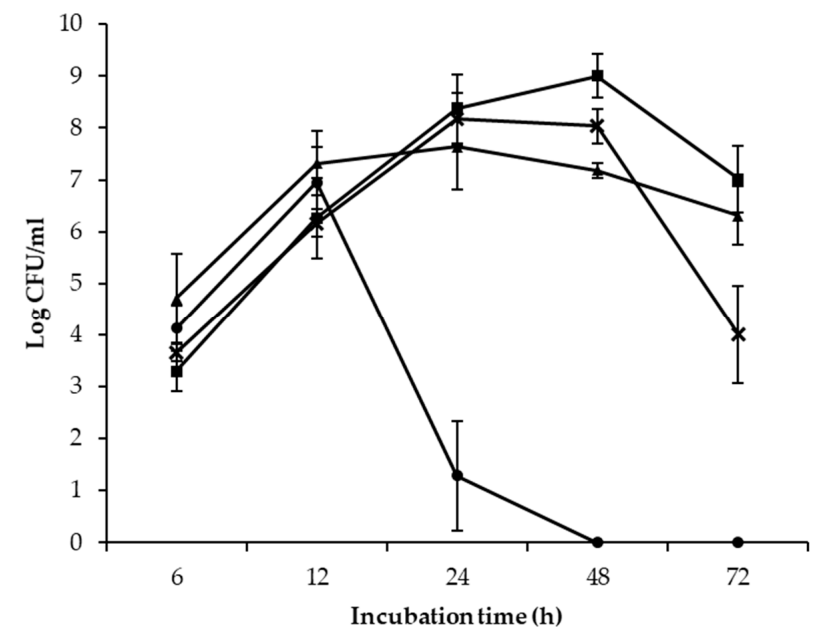

Figure 2. Mean population s of all four S. enterica and E. coli when co-cultured with L. rhamnousus GG at $37^{\circ} \mathrm{C}\left(\right.$ S. enterica $\longrightarrow$; E. coli $\longrightarrow$ ) and $25^{\circ} \mathrm{C}($ S. enterica $\longrightarrow$; E. coli -$)$ after 6, 12, 24, 48, and $72 \mathrm{~h}$ of incubation. 


\subsection{Competitive Attachment to Vegetable Seeds by Salmonella/EHEC as Affected by Bacterial Competitors}

The mean percentages of attached cells of Salmonella or EHEC cocktail to the four types of vegetable seeds were significantly lower $(p<0.05)$ when the competitive bacterial strains were present (Table 5). When no competitive bacterial strains were used, the mean percentage of attachment of Salmonella and EHEC cells were 10.5\% and 3.9\%, respectively. In the co-cultures with P. fluorescens A506, both Salmonella and EHEC strains had the lowest percentages of attachment, 7 and $2.4 \%$, respectively, on the vegetable seeds. The percentages of attachment of Salmonella in the co-cultures with B. mojavensis RRC $101(7.9 \%)$, B. subtilis ATCC $6051(8.1 \%)$, and Pst DC $3000(8.2 \%)$ were statistically similar $(p>0.05)$ but were significantly lower than the percentage of attachment in co-cultures with L. rhamnosus GG $(9.4 \%)$ and the competing cocktail $(9.0 \%)$. Except for the controls, the highest percentages of attachment of EHEC were seen in the co-cultures with L. rhamnosus GG $(3.4 \%)$ and Pst DC3000 (3.5\%), followed by the bacterial cocktail (3.1\%), B. mojavensis RRC $101(2.9 \%)$, and B. subtilis ATCC $6051(2.8 \%)$. The percentages of attachment of both Salmonella and EHEC cells were the highest on fenugreek seeds $(12.5 \%$ and $6.7 \%)$, followed by alfalfa $(11.8 \%$ and $2.0 \%)$ and lettuce $(8.9 \%$ and $1.7 \%)$ seeds. No attachment was detectable from tomato seeds used in the study.

Table 5. Mean percentages of attached cells of the four-strain S. enterica or EHEC mixtures as affected by individual competitive bacterial strains and their cocktail.

\begin{tabular}{ccc}
\hline & \multicolumn{2}{c}{ Percentage (\%) of Attached Cells } \\
\cline { 2 - 3 } & Salmonella $^{\mathbf{1}(\boldsymbol{n}=\mathbf{8 4})}$ & EHEC $(\boldsymbol{n}=\mathbf{8 4})$ \\
\hline As influenced by competitive strains & & \\
Control $(n=12)$ & $10.5 \pm 0.38 \mathrm{~A}$ & $3.9 \pm 0.14 \mathrm{~A}$ \\
L. rhamnosus GG $(n=12)$ & $9.4 \pm 0.33 \mathrm{~B}$ & $3.4 \pm 0.11 \mathrm{~B}$ \\
Cocktail 2 $2(n=12)$ & $9.0 \pm 0.29 \mathrm{C}$ & $3.1 \pm 0.18 \mathrm{C}$ \\
B. mojavensis RRC 101 $(n=12)$ & $7.9 \pm 0.21 \mathrm{D}$ & $2.9 \pm 0.16 \mathrm{C}$ \\
B. subtilis ATCC 6051 $(n=12)$ & $8.1 \pm 0.24 \mathrm{D}$ & $2.8 \pm 0.23 \mathrm{C}$ \\
P. syringae pv. tomato DC 3000 $(n=12)$ & $8.2 \pm 0.27 \mathrm{D}$ & $3.5 \pm 0.20 \mathrm{~B}$ \\
P. fluorescenes A506 $(n=12)$ & $7.0 \pm 0.20 \mathrm{E}$ & $2.4 \pm 0.12 \mathrm{D}$ \\
On different seed types & & \\
Fenugreek $(n=21)$ & $12.5 \pm 0.19 \mathrm{~A}$ & $6.7 \pm 0.11 \mathrm{~A}$ \\
Alfalfa $(n=21)$ & $11.8 \pm 0.08 \mathrm{~B}$ & $2.0 \pm 0.08 \mathrm{~B}$ \\
Lettuce $(n=21)$ & $8.9 \pm 0.08 \mathrm{C}$ & $1.7 \pm 0.04 \mathrm{C}$ \\
Tomato $(n=21)$ & $\mathrm{ND}^{3}$ & $\mathrm{ND}$ \\
\hline
\end{tabular}

${ }^{1}$ Mean percentages of attachment within a column not followed by the same letter are significantly different $(p<0.05) .{ }^{2}$ Cocktail 2: A mixed culture of P. fluorescenes AS06, B. mojavensis RRC 101, B. subtilis ATCC 6051, and L. rhamnosus GG. ${ }^{3}$ Attachment not detected.

\subsection{Inhibition of Salmonella and EHEC by the CFS of L. rhamnousus GG Spent Cultures}

Changes in the mean population of all four Salmonella and EHEC strains grown in PBS amended with the CFS of 72-h spent cultures of the three individual biocontrol agents and L. rhamnousus GG are shown in Figure 3. The addition of L. rhamnousus GG CFS to the diluted Salmonella and EHEC cultures resulted in significant $(p<0.05)$ reductions in the populations of Salmonella and EHEC. The mean populations of the four Salmonella strains reduced approximately $1 \log$ unit after $2 \mathrm{~h}$ of incubation. Salmonella cells became undetectable $(<10 \mathrm{CFU} / \mathrm{mL})$ at the $12 \mathrm{~h}$ sampling point and forward. At the $24 \mathrm{~h}$ sampling point, a total of $5 \log$ unit reduction was achieved. During the incubation period from the $4 \mathrm{~h}$ to $6 \mathrm{~h}$ sampling point, the mean population of the four EHEC strains decreased by $2.4 \log \mathrm{CFU} / \mathrm{mL}$. A total of $4 \log \mathrm{CFU} / \mathrm{mL}$ reduction was observed after the $24 \mathrm{~h}$ incubation period. In comparison, the growth of Salmonella and EHEC in other co-cultures was not inhibited and the pathogen populations increased exponentially before entering the stationary phase after $24 \mathrm{~h}$ of incubation. The populations of Salmonella and EHEC recovered from these co-cultures did not differ from each other throughout the incubation 
period, with the maximum population difference of $0.6 \log$ units for Salmonella and $0.4 \log$ units for EHEC.

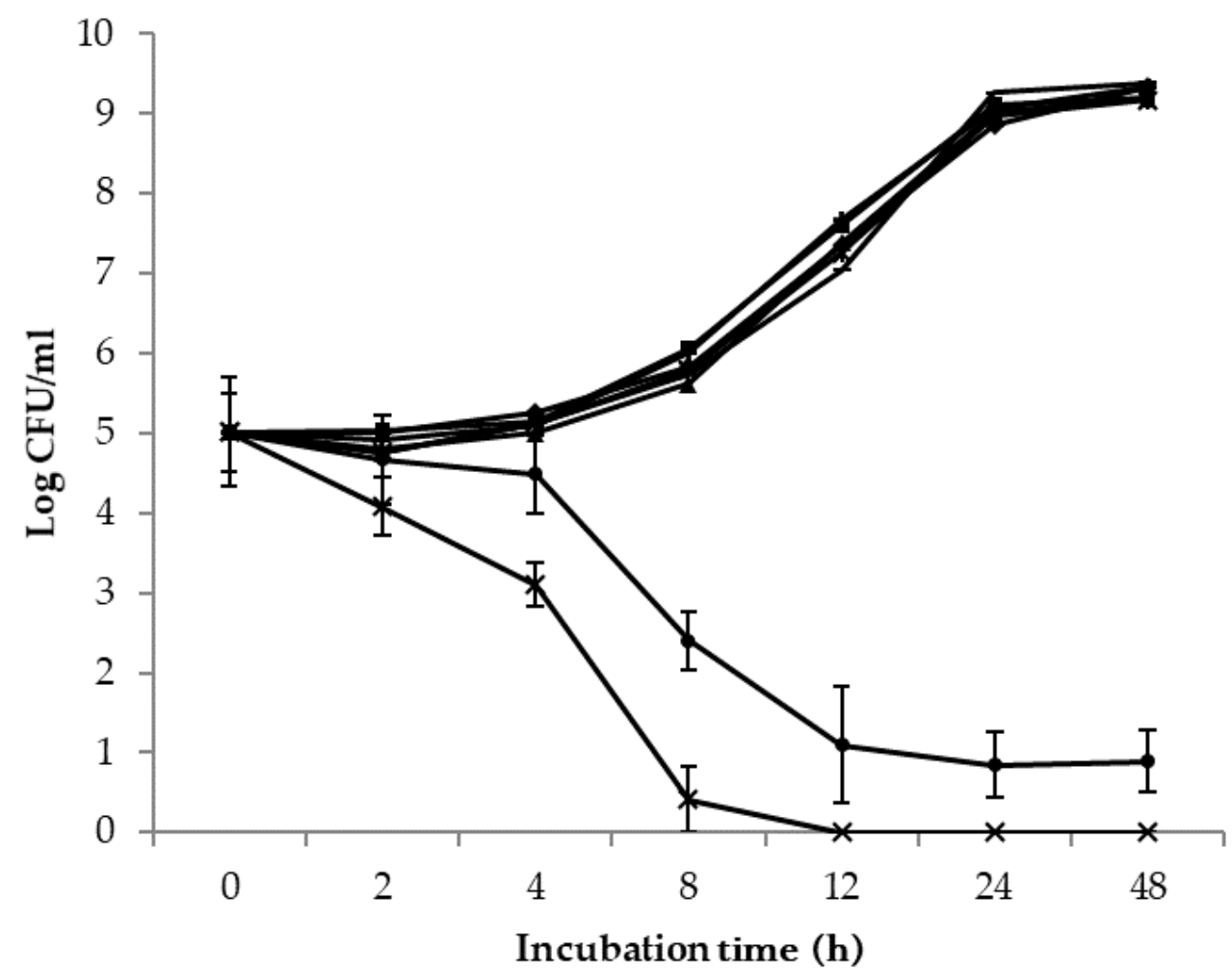

Figure 3. Mean populations of all four S. enterica and EHEC cultured in PSB amended with the cell-free supernatants of P. fluorescenes A506 (S. enterica $\mathbf{\star}^{-}$; EHEC ${ }^{*}$ ) ), B. subtilis ATCC 6051 (S. enterica - - ; EHEC - ) , B. mojavensis RRC 101 (S. enterica -; EHEC — ) and L. rhamnousus GG (S. enterica $\multimap$; EHEC $\longrightarrow$ ) ) at the 2, 4, 8, 12, 24 and 48 h sampling points.

The responses of the four individual Salmonella or EHEC strains to the CFS of L. rhamnousus GG over the 48-h incubation period are shown in Figure 4. The population of the four Salmonella strains decreased rapidly after $4 \mathrm{~h}$ of incubation, and populations of $S$. Baildon and $S$. Cubana fell below the detection limit of plate count assay after $8 \mathrm{~h}$ of incubation (Figure 4a). S. Montevideo and S. Stanley cells were not detectable after $12 \mathrm{~h}$ of incubation. The population of all 4 EHEC strains also decreased rapidly after the initial $4 \mathrm{~h}$ of incubation, and cells of E. coli BAA 2326 became undetectable after $12 \mathrm{~h}$ of incubation in PBS amended with CFS (Figure 4b). Cells of E. coli F4546 and H1730 were detectable till $24 \mathrm{~h}$ of incubation. However, the population of K4492 increased to 3.3 and $3.5 \log \mathrm{CFU} / \mathrm{mL}$ at the 24 and $48 \mathrm{~h}$ sampling points after dropping from the $5.2 \log \mathrm{CFU} / \mathrm{mL}$ inoculation level to $2.7 \log \mathrm{CFU} / \mathrm{mL}$ during the initial $12 \mathrm{~h}$ of incubation. 
(a)

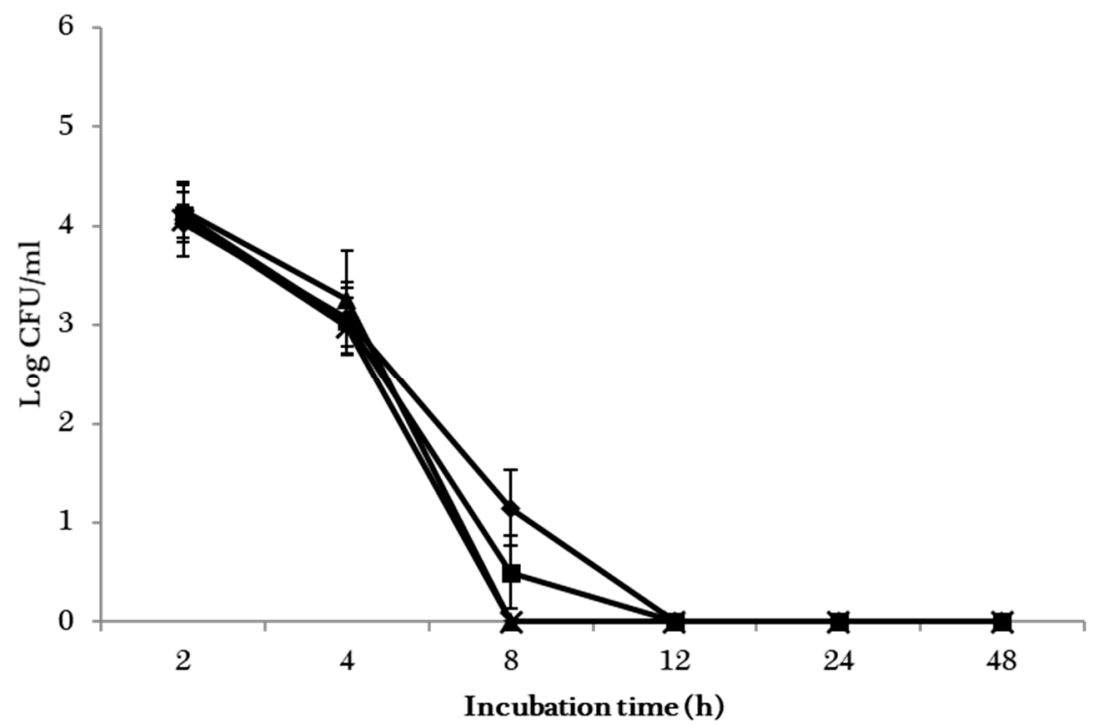

(b)

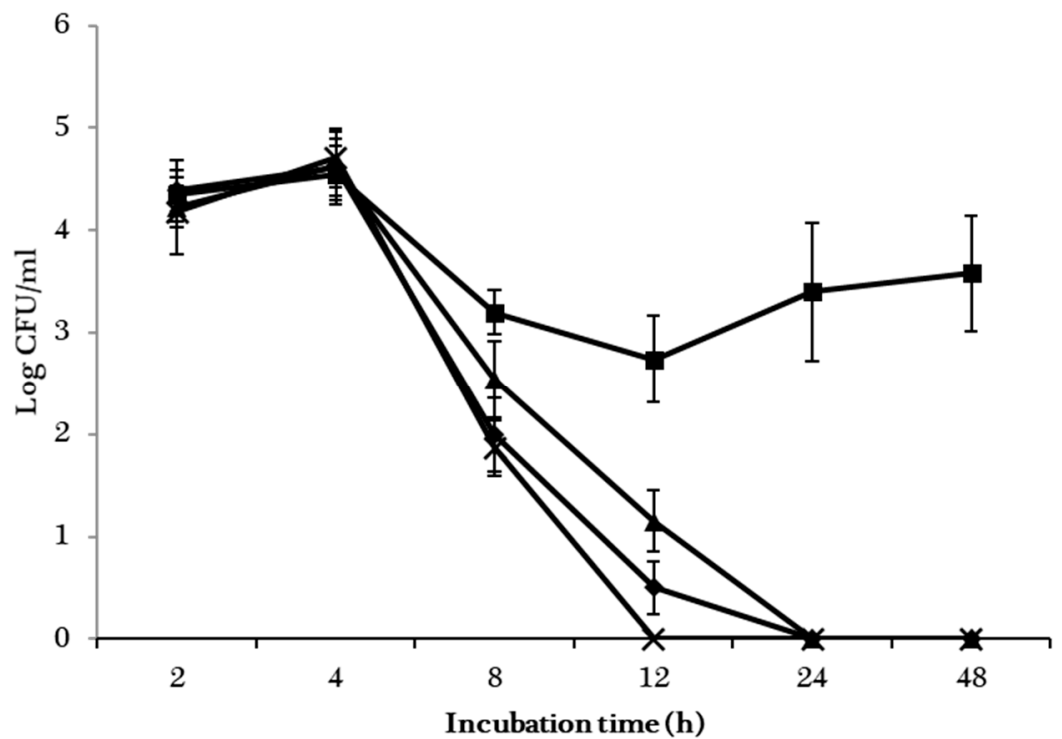

Figure 4. Mean populations of individual S. enterica (a) and E. coli (b) strains grown in PSB amended with cell-free supernatant of L. rhamnousus GG for 2, 4, 8, 12, 24, and $48 \mathrm{~h}$. The strains included were S. Montevideo and E. coli F4546 (-• ), S. Stanley and E. coli K4492 (-), S. Cubana and E. coli $\mathrm{H} 1730(\leftarrow)$, as well as $S$. Baildon and E. coli BAA-2326 ( $\lessdot$ ).

\section{Discussion}

Results of the overall statistical analysis showed that co-cultures with L. rhamnousus GG had the lowest Salmonella and EHEC populations at both 25 and $37^{\circ} \mathrm{C}$ compared to the co-cultures with other bacterial competitors (Table 2). Production of various organic acids and antimicrobial peptides including bacteriocin by L. rhamnousus GG might be the underlying mechanisms of the observed phenomenon. Organic acids can lower the $\mathrm{pH}$ of microbiological media and consequently inhibit the growth of bacterial pathogens [23]. Bacteriocins are proteinaceous or peptidic toxins produced by bacterial cells, which can kill susceptible pathogens by changing the permeability of bacterial membranes or interfering with the biological function of essential bacterial enzymes [24]. Distinct from the antimicrobial peptides produced by other Lactobacillus spp., those produced by L. rhamnousus GG belong to the least-characterized class of complex bacteriocin which had a broad spectrum 
of antagonistic activity against Gram-positive and Gram-negative organisms [24]. Previous studies have shown that the bacteriocin produced by L. rhamnousus GG can also inhibit the growth of some plant pathogens such as Pseudomonas aeruginosa and several major food spoilage microorganisms $[25,26]$. These findings suggest that the probiotic bacterium has a potential application as a biological control agent for improving the microbial safety of vegetable seeds, particularly sprout seeds.

When L. rhamnousus GG was co-cultured with Salmonella or EHEC at $25{ }^{\circ} \mathrm{C}$, the incubation time required for observable pathogen inhibition was relatively longer than incubation at $37^{\circ} \mathrm{C}$. Furthermore, Salmonella and EHEC population differences were much smaller between different sampling points at $25^{\circ} \mathrm{C}$ (Figure 2). The relatively lower antagonistic ability of L. rhamnousus GG at $25^{\circ} \mathrm{C}$ might be the result of a slower growth pace and accumulation of pathogen-cidal metabolites since this incubation temperature was less than optimal [23]. The growth rates of L. rhamnousus GG in MRS broth ( $\mathrm{pH} 6.5$ ) at $37^{\circ} \mathrm{C}$ and $25^{\circ} \mathrm{C}$ were reported as 0.95 and $0.36 \mathrm{OD} 600 / \mathrm{h}$, respectively [27]. At $25^{\circ} \mathrm{C}$, the maximum L. rhamnousus GG population was 0.5-1.5 OD600 readings lower, and the time required for L. rhamnousus GG to reach the stationary phase was about $12 \mathrm{~h}$ longer than at $37^{\circ} \mathrm{C}$. When grown in UHT milk for $48 \mathrm{~h}$, the amount of organic acids and acetaldehyde produced by L. rhamnousus GG at $30^{\circ} \mathrm{C}$ was found significantly lower than at $37^{\circ} \mathrm{C}$ [28]. FayolMessaoudi and coworkers [23] observed that when incubated at $32{ }^{\circ} \mathrm{C}$, the killing activity of CFSs of the 24 h-culture of L. rhamnousus GG was significantly lower, although the lactic acid concentration in CFSs did not differ significantly from that at $37^{\circ} \mathrm{C}$. It is believed that the production of pathogen-cidal metabolites other than organic acid is also affected by the incubation temperature used to cultivate the probiotic bacterium.

In general, lower $(p<0.05)$ populations of Salmonella than EHEC were observed in the co-cultures with L. rhamnousus GG (Table 2) or in PBS supplemented with its CFS (Figure 3). Similar observations were made by Arias and co-workers [29] who reported that the inhibition of L. rhamnousus and its CFS to $S$. Typhimurium was significantly stronger than to E. coli O157:H7. E. coli O157 strains are known to be more acid-resistant than Salmonella at $\mathrm{pH}$ from 2.5, 3.5, to 3.8 [30]. Higher tolerance of E. coli O157 to acetic acid and lactic acid were also reported [31,32]. Since the production of organic acid and the resulting low environmental $\mathrm{pH}$ are among the important antagonistic mechanisms utilized by L. rhamnousus GG [33], the ability of E. coli $\mathrm{O} 157$ to better adapt to the acidic environment might have contributed to the lower inhibitory effects of L. rhamnousus GG and its CFS observed in the present study. E. coli O104:H4 strain BAA 2326 used in the present study had a similar response to co-culture with L. rhamnousus GG and in PBS supplemented with its CFS compared to the two O157 strains, F4546, and H1730 (Figure 4b). The higher cell counts of E. coli K4492 in co-cultures with L. rhamnousus GG CFS indicates that the resistance of EHEC to the metabolites of L. rhamnousus GG is likely strain dependent.

Commercially used as a biocontrol agent, P. fluorescens A506 is known to compete with plant pathogen E. amylovora via preemptive utilization of growth-limiting nutrients at growth niches such as nactaries of pear blossoms [34]. In the present study, the use of a 100-fold higher start inoculum of P. fluorescens A506 over the tested Salmonella and EHEC strains resulted in a significant $(p<0.05)$, but overall a less than 1 log unit difference in Salmonella and EHEC population during the $72 \mathrm{~h}$ co-incubation period (Tables 2-4). The observed population reduction is likely the result of competition for nutrients by P. fluorescens A506 as the CFS of P. fluorescens A506 did not cause observable inhibition of Salmonella and EHEC (Figure 3). A similar observation has been noticed in several earlier studies. The presence of a $P$. fluorescens strain in the mixed culture with E. coli O157:H7 ATCC 43895 reportedly reduced the pathogen population overtime at 10, 15, and $25{ }^{\circ} \mathrm{C}$ [35]. The incubation temperature of $25^{\circ} \mathrm{C}$ might also provide $P$. fluorescens A506 competition advantages over the two human pathogens, as the optimal growth temperature of P. fluorescens A506 is $25^{\circ} \mathrm{C}$ while that of Salmonella and EHEC is $37^{\circ} \mathrm{C}$.

Slight, but significant $(p<0.05)$ differences in Salmonella and EHEC populations were observed when they were co-cultured with B. mojavensis RRC101 and B. subtilis ATCC6051 
compared to the pathogen populations in the control cultures (Table 2). The antagonistic activities of the two biocontrol agents were reported to rely on the release of specific fungicidal cyclic lipopeptides and/or bio-surfactants [36,37]. Whether the bio-surfactants can effectively inhibit the growth of Salmonella and EHEC remains contradictory. The surfactin extracted from the 7-day culture of B. licheniformis M104 inhibited the growth of $S$. Typhimurium ATCC 14028 and two E. coli strains ATCC 11775 and 11246 in a disc diffusion assay [38]. However, Mireles and coworkers found that surfactins of B. subtilis could only inhibit biofilm formation, but not the growth of S. enterica and E. coli cells [39]. The slight reductions in Salmonella and EHEC populations resulted from the co-presence of B. mojavensis RRC101 and B. subtilis ATCC 6051 in the present study are likely the result of another mechanism such as the competition for nutrients in microbiological media.

Using multiple biocontrol agents simultaneously could be one of the solutions to the unsatisfactory inhibition to target pathogen(s) by individual biocontrol agents. Knowing the inhibitory mechanisms of each biocontrol agent is crucial in finding the most efficient components of a biological control cocktail, ideally, different modes of action can be applied simultaneously to avoid possible adaption of the target pathogen(s) [40]. It is also important to understand if synergistic/antagonistic effects exist among all candidates used in the same cocktail. Ye and coworkers [16] previously reported the success in using a combination of plant bacterium E. asburiae JX1 and a cocktail of Salmonella lytic phages to achieve a 3-log unit reduction in the Salmonella population on sprouting mung bean and alfalfa seeds. Other studies also described the potential of using cocktails of antagonistic strains in the control of various plant and human pathogens [40-42]. In the current study, slightly lower pathogen populations were observed when the two cocktails were used (Table 2). It is not yet clear if the slightly larger pathogen population differences caused by the presence of the two cocktails were the results of synergetic interactions among the biocontrol agents or simply the effect of a greater overlap of nutrition requirements among cells of multiple biocontrol agents and Salmonella/EHEC strains. Further research is needed to fully understand and improve the inhibitory effects of the cocktails on human pathogens in the co-culture systems.

Although the presence of L. rhamnousus GG in a co-culture had the lowest Salmonella and EHEC populations, adding L. rhamnousus GG to Cocktail 1 did not significantly $(p>0.05)$ change the ability of the biocontrol cocktail in inhibiting the growth of Salmonella (Table 2). The reduction in the EHEC population caused by the presence of the two cocktails differed only by $0.1 \log$ units. It was found in the study that the $\mathrm{pH}$ of $72-\mathrm{h}$ mixed cultures containing Cocktail 2 and Salmonella or EHEC ranged from 6.8 to 7.2, which was higher than the $\mathrm{pH}$ of 3.7-4.3 from the co-cultures of L. rhamnousus GG with Salmonella/EHEC (data not shown). This indicates a poor L. rhamnousus GG growth in the mixed culture containing Cocktail 2, subsequently a low level of accumulation of anti-Salmonella and -EHEC metabolites in the cocktail. Since the biocontrol agents used in Cocktail 2 had an optimal growth temperature of $25^{\circ} \mathrm{C}$, L. rhamnousus GG was likely to be outgrown by the biocontrol agents in the cocktail at this incubation temperature. The relatively higher $\mathrm{pH}$ in Cocktail 2 could also affect the function of non-organic acid antimicrobial molecules produced by L. rhamnousus GG. It has been reported that the antagonistic compounds produced by L. rhamnousus GG suppressed the growth of $S$. Typhimurium at $\mathrm{pH} 4.5$ but not at $\mathrm{pH} 6.5$ [23]. Synergistic effects between lactic acid and non-lactic acid antimicrobial molecules released by Lactobacillus strains have been described by Alakomi and coworkers [43] who reported that the lactic acid molecules can modify the permeability of the outer membrane of gram-negative pathogens, allowing antimicrobial molecules to more easily across cell membranes of the target bacteria. As stated previously, a good biocontrol cocktail should not contain bacterial strains which are antagonistic with one another.

Although not as competitive as L. rhamnousus GG in inhibiting the growth of Salmonella and EHEC, the three biocontrol agents significantly $(p<0.05)$ reduced the attachment of Salmonella and EHEC cells to tested vegetable seeds (Table 5). The lower level of Salmonella 
and EHEC attachment caused by the co-presence of these bacterial strains might partially result from the competition among cells of participating bacterial strains including those of human pathogens for limited niches of attachment on vegetable seeds. Ideal attachment niches for microorganisms usually include the wrinkles, cracks, and crevices on the surface of vegetable seeds [44]. The production of surfactin-like molecules by L. rhamnousus GG [45] and the two Bacillus strains [37] might have interfered with the attachment by Salmonella and E. coli cells to seed surfaces. Most significant reductions in Salmonella and EHEC attachment to vegetable seeds were observed when P. fluorescens A506 was present. The reason for the observed phenomenon is unclear, but it may because $P$. fluorescens is a better colonizer that can attach firmly to seeds, roots, and various plant tissues in the presence of many other competitive plant microorganisms [46].

The interactions between plant and human pathogens have been discussed widely as plant pathogens might play a role in the survival of human pathogens within various plant hosts $[47,48]$. Certain activities of plant pathogens (e.g., breach of plant cell walls, the necrotic release of nutrients from plant cells and suppression of plant immunity, etc.) might boost the survival of human pathogens that are present in nearby proximity. Esseilli and coworkers [49] reported that the necrotic lesions created by Xanthomonas campestris pv. vitians or cucumber mosaic virus strain Fny enhanced the postharvest survival of human pathogens on leafy green vegetables. Water-soaking of tomato leaves from the infection by $X$. euvesicatoria and X. gardneri supported the persistence and/or growth of S. enterica [50]. The majority of the known interactions between plant and human pathogens were observed within mature plant hosts. Although P. syringae and its multiple pathovars (e.g., syringae, tomato) have been reported to enhance the survival and growth of $S$. Typhimurium and pathogenic E. coli on leaves of different plants [51], Pst DC3000 in the current study only slightly inhibited the growth of the two pathogens (Table 2). Whether and how the two types of pathogens interact with each other outside mature plants, such as on vegetable seeds and seedlings, demands further, and more systematic investigation.

\section{Conclusions}

Biological control of human pathogens on vegetable seeds at both pre- and postharvest stages has drawn the attention of many researchers, as it can lead to the production of vegetable seeds and fresh produce with high microbial qualities. In this study, significantly lower populations of Salmonella and EHEC were observed when they were in co-cultures with L. rhamnousus GG in M/T broth and PBS supplemented with L. rhamnousus GG CFS. Since L. rhamnousus GG is a probiotic organism and its beneficial effect on human gut health has been proven in numerous clinical trials, it could be a potential biocontrol agent to improve the microbial safety of vegetable seeds, especially at postharvest stages. Although not as competitive as L. rhamnousus GG in inhibiting the growth of Salmonella and EHEC, the three biocontrol agents were more effective in competing with Salmonella and EHEC for attachment to vegetable seeds. Thus, in addition to the control of plant pathogens, these agents could also be used to control human pathogens during vegetable seed production. The different responses of the S. enterica and EHEC strains to each competitive bacterium and cocktails highlight the importance of choosing appropriate biocontrol agent(s) for targeted pathogens. Future studies should focus on the identification of additional effective competitive bacterial strains with negligible adverse influences on seed/fresh produce quality as well as a better understanding of the synergetic mechanisms among participating bacterial strains to maximize their antagonistic effects. The effectiveness of the identified biocontrol agents should be verified during pilot trials of vegetable seed production and storage after laboratory evaluations.

Author Contributions: Conceptualization, J.C. and R.W.; methodology, D.L. and J.C.; formal analysis, D.L.; data curation, D.L. and K.M.S.; writing-original draft preparation, D.L.; writing-review and editing, D.L and J.C.; supervision, J.C. and R.W.; project administration, J.C.; funding acquisition, J.C. and R.W. All authors have read and agreed to the published version of the manuscript. 
Funding: This material is based upon work that is supported by the National Institute of Food and Agriculture, U.S. Department of Agriculture, under award number 2014-67017-21705.

Institutional Review Board Statement: The study was approved by the University of Georgia Institutional Biosafety Committee (protocol code 2013-0052).

Data Availability Statement: The datasets generated for this study are available on request to the corresponding author.

Conflicts of Interest: The authors declare no conflict of interest. The funders had no role in the design of the study; in the collection, analyses, or interpretation of data; in the writing of the manuscript, or in the decision to publish the results.

\section{References}

1. Como-Sabetti, K.; Reagan, S.; Allaire, S.; Parrott, K.; Simonds, C.; Hrabowy, S.; Ritter, B.; Hall, W.; Altamirano, J.; Martin, R. Outbreaks of Escherichia coli O157:H7 infection associated with eating alfalfa sprouts-Michigan and Virginia, June-July 1997. Morb. Mortal. Wkly. Rep. 1997, 46, 741-744.

2. Mahon, B.E.; Pönkä, A.; Hall, W.N.; Komatsu, K.; Dietrich, S.E.; Siitonen, A.; Cage, G.; Hayes, P.S.; Lambert-Fair, M.A.; Bean, N.H. An international outbreak of Salmonella infections caused by alfalfa sprouts grown from contaminated seeds. J. Infect. Dis. 1997, 175, 876-882. [CrossRef]

3. Winthrop, K.; Palumbo, M.; Farrar, J.; Mohle-Boetani, J.; Abbott, S.; Beatty, M.; Inami, G.; Werner, S. Alfalfa sprouts and Salmonella Kottbus infection: A multistate outbreak following inadequate seed disinfection with heat and chlorine. J. Food Prot. 2003, 66, 13-17. [CrossRef]

4. Taormina, P.J.; Beuchat, L.R.; Slutsker, L. Infections associated with eating seed sprouts: An international concern. Emerg. Inf. Dis. 1999, 5, 626. [CrossRef]

5. Howard, M.B.; Hutcheson, S.W. Growth dynamics of Salmonella enterica strains on alfalfa sprouts and in waste seed irrigation water. Appl. Environ. Microbiol. 2003, 69, 548-553. [CrossRef]

6. Deering, A.J.; Jack, D.R.; Pruitt, R.E.; Mauer, L.J. Movement of Salmonella serovar Typhimurium and E. coli O157:H7 to ripe tomato fruit following various routes of contamination. Microorganisms 2015, 3, 809-825. [CrossRef] [PubMed]

7. Andrews, W.; Hammack, T.; Amaguana, R. Chapter 5, Salmonella. In Bacteriological Analytical Manual. US Food and Drug Administration. 2007. Available online: http://www.cfsan.fda.gov/ebam/bam-5.htm (accessed on 8 October 2020).

8. Feng, P.; Weagant, S.; Jinneman, K. Bacteriological Analytical Manual, Chapter 4A, Diarrheagenic Escherichia coli. Available online: http:/ / www.fda.gov/Food/FoodScienceResearch/LaboratoryMethods/ucm070080.htm (accessed on 11 December 2019).

9. Fett, W. Factors affecting the efficacy of chlorine against Escherichia coli O157:H7 and Salmonella on alfalfa seed. Food Microbiol. 2002, 19, 135-149. [CrossRef]

10. Cooley, M.B.; Miller, W.G.; Mandrell, R.E. Colonization of Arabidopsis thaliana with Salmonella enterica and enterohemorrhagic Escherichia coli O157:H7 and competition by Enterobacter asburiae. Appl. Environ. Microbiol. 2003, 69, 4915-4926. [CrossRef] [PubMed]

11. Davidson, P.M.; Harrison, M.A. Resistance and adaptation to food antimicrobials, sanitizers, and other process controls. Food Technol. 2002, 56, 69-78.

12. Kamilova, F.; Kravchenko, L.V.; Shaposhnikov, A.I.; Makarova, N.; Lugtenberg, B. Effects of the tomato pathogen Fusarium oxysporum f. sp. radicis-lycopersici and of the biocontrol bacterium Pseudomonas fluorescens WCS365 on the composition of organic acids and sugars in tomato root exudate. Mol. Plant-Microbe Interact. 2006, 19, 1121-1126. [PubMed]

13. Kamilova, F.; Validov, S.; Azarova, T.; Mulders, I.; Lugtenberg, B. Enrichment for enhanced competitive plant root tip colonizers selects for a new class of biocontrol bacteria. Environ. Microbiol. 2005, 7, 1809-1817. [CrossRef] [PubMed]

14. Fessehaie, A.; Walcott, R. Biological control to protect watermelon blossoms and seed from infection by Acidovorax avenae subsp. citrulli. Phytopathology 2005, 95, 413-419. [CrossRef] [PubMed]

15. Liao, C.H. Growth of Salmonella on sprouting alfalfa seeds as affected by the inoculum size, native microbial load and Pseudomonas fluorescens 2-79. Lett. Appl. Microbiol. 2008, 46, 232-236. [CrossRef] [PubMed]

16. Ye, J.; Kostrzynska, M.; Dunfield, K.; Warriner, K. Control of Salmonella on sprouting mung bean and alfalfa seeds by using a biocontrol preparation based on antagonistic bacteria and lytic bacteriophages. J. Food Prot. 2010, 73, 9-17. [CrossRef] [PubMed]

17. Compant, S.; Duffy, B.; Nowak, J.; Clément, C.; Barka, E.A. Use of plant growth-promoting bacteria for biocontrol of plant diseases: Principles, mechanisms of action, and future prospects. Appl. Environ. Microbiol. 2005, 71, 4951-4959. [CrossRef]

18. Cabrefiga, J.; Bonaterra, A.; Montesinos, E. Mechanisms of antagonism of Pseudomonas fluorescens EPS62e against Erwinia amylovora, the causal agent of fire blight. Int. Microbiol. 2007, 10, 123.

19. Bredholt, S.; Nesbakken, T.; Holck, A. Industrial application of an antilisterial strain of Lactobacillus sakei as a protective culture and its effect on the sensory acceptability of cooked, sliced, vacuum-packaged meats. Int. J. Food Microbiol. 2001, 66, 191-196. [CrossRef]

20. Nitschke, M.; Araújo, L.; Costa, S.; Pires, R.; Zeraik, A.; Fernandes, A.; Freire, D.; Contiero, J. Surfactin reduces the adhesion of food-borne pathogenic bacteria to solid surfaces. Lett. Appl. Microbiol. 2009, 49, 241-247. [CrossRef] 
21. De Keersmaecker, S.C.; Verhoeven, T.L.; Desair, J.; Marchal, K.; Vanderleyden, J.; Nagy, I. Strong antimicrobial activity of Lactobacillus rhamnosus GG against Salmonella typhimurium is due to accumulation of lactic acid. FEMS Microbiol. Lett. 2006, 259, 89-96. [CrossRef]

22. Cui, Y.; Walcott, R.; Chen, J. Differential attachment of Salmonella enterica and enterohemorrhagic Escherichia coli to alfalfa, fenugreek, lettuce, and tomato seeds. Appl. Environ. Microbiol. 2017, 83, e03170-16. [CrossRef]

23. Fayol-Messaoudi, D.; Berger, C.N.; Coconnier-Polter, M.-H.; Lievin-Le Moal, V.; Servin, A.L. pH-, lactic acid-, and non-lactic acid-dependent activities of probiotic lactobacilli against Salmonella enterica serovar Typhimurium. Appl. Environ. Microbiol. 2005, 71, 6008-6013. [CrossRef] [PubMed]

24. Pithva, S.; Ambalam, P.; Dave, J.; Vyas, B. Antimicrobial Peptides of Probiotic Lactobacillus Strains. 2011. Available online: https:/ /www.researchgate.net/publication/258338154_Antimicrobial_Peptides_of_Probiotic_Lactobacillus_strains (accessed on 8 October 2020).

25. Alexandre, Y.; Le Berre, R.; Barbier, G.; Le Blay, G. Screening of Lactobacillus spp. for the prevention of Pseudomonas aeruginosa pulmonary infections. BMC Microbiol. 2014, 14, 107. [CrossRef] [PubMed]

26. Tharmaraj, N.; Shah, N.P. Antimicrobial effects of probiotics against selected pathogenic and spoilage bacteria in cheese-based dips. Int. Food. Res. J. 2009, 16, 261-276.

27. Deepika, G.; Karunakaran, E.; Hurley, C.R.; Biggs, C.A.; Charalampopoulos, D. Influence of fermentation conditions on the surface properties and adhesion of Lactobacillus rhamnosus GG. Microb. Cell Factories 2012, 11, 116. [CrossRef] [PubMed]

28. Østlie, H.M.; Treimo, J.; Narvhus, J.A. Effect of temperature on growth and metabolism of probiotic bacteria in milk. Int. Dairy J. 2005, 15, 989-997. [CrossRef]

29. Arias, O.A.; Reyes, M.M.; Navarro, V.M.L.; Solis, C.Y.; Márquez, G.M.; Sanchez, S.G.; Snell, C.R.; Zuñiga, R.R. Antagonistic Effect of Probiotic Strains against Two Pathogens: Salmonella Typhimurium and E. coli O157:H7 Resistant to Antibiotics. Available online: https:/ / www.redalyc.org/pdf/730/73029399005.pdf (accessed on 8 October 2020).

30. Breidt, F., Jr.; Kay, K.; Cook, J.; Osborne, J.; Ingham, B.; Arritt, F. Determination of 5-log reduction times for Escherichia coli O157:H7, Salmonella enterica, or Listeria monocytogenes in acidified foods with pH 3.5 or 3.8. J. Food Prot. 2013, 76, 1245-1249. [CrossRef] [PubMed]

31. Berry, E.D.; Cutter, C.N. Effects of acid adaptation of Escherichia coli O157:H7 on efficacy of acetic acid spray washes to decontaminate beef carcass tissue. Appl. Environ. Microbiol. 2000, 66, 1493-1498. [CrossRef] [PubMed]

32. Brackett, R.; Hao, Y.-Y.; Doyle, M. Ineffectiveness of hot acid sprays to decontaminate Escherichia coli O157:H7 on beef. J. Food Prot. 1994, 57, 198-203. [CrossRef]

33. Vanderhoof, J.A.; Whitney, D.B.; Antonson, D.L.; Hanner, T.L.; Lupo, J.V.; Young, R.J. Lactobacillus GG in the prevention of antibiotic-associated diarrhea in children. J. Pediatr. 1999, 135, 564-568. [CrossRef]

34. Stockwell, V.; Johnson, K.; Sugar, D.; Loper, J. Control of fire blight by Pseudomonas fluorescens A506 and Pantoea vagans C9-1 applied as single strains and mixed inocula. Phytopathology 2010, 100, 1330-1339. [CrossRef]

35. Samelis, J.; Sofos, J.N. Role of glucose in enhancing the temperature-dependent growth inhibition of Escherichia coli O157:H7 ATCC 43895 by a Pseudomonas sp. Appl. Environ. Microbiol. 2002, 68, 2600-2604. [CrossRef] [PubMed]

36. Bacon, C.W.; Hinton, D.M. Endophytic and biological control potential of Bacillus mojavensis and related species. Biol. Control 2002, 23, 274-284. [CrossRef]

37. Snook, M.E.; Mitchell, T.; Hinton, D.M.; Bacon, C.W. Isolation and characterization of Leu7-surfactin from the endophytic bacterium Bacillus mojavensis RRC 101, a biocontrol agent for Fusarium verticillioides. J. Agric. Food Chem. 2009, 57, 4287-4292. [CrossRef] [PubMed]

38. Gomaa, E.Z. Antimicrobial activity of a biosurfactant produced by Bacillus licheniformis strain M104 grown on whey. Braz. Arch Biol. Technol. 2013, 56, 259-268. [CrossRef]

39. Mireles, J.R.; Toguchi, A.; Harshey, R.M. Salmonella enterica serovar Typhimurium swarming mutants with altered biofilm-forming abilities: Surfactin inhibits biofilm formation. J. Bacteriol. 2001, 183, 5848-5854. [CrossRef]

40. Vijayakumar, P.P.; Muriana, P.M. Inhibition of Listeria monocytogenes on ready-to-eat meats using bacteriocin mixtures based on mode-of-action. Foods 2017, 6, 22. [CrossRef]

41. Bonaterra, A.; Badosa, E.; Cabrefiga, J.; Francés, J.; Montesinos, E. Prospects and limitations of microbial pesticides for control of bacterial and fungal pomefruit tree diseases. Trees 2012, 26, 215-226. [CrossRef]

42. Nisbet, D. Defined competitive exclusion cultures in the prevention of enteropathogen colonisation in poultry and swine. Antonie Leeuwenhoek 2002, 81, 481-486. [CrossRef]

43. Alakomi, H.-L.; Skyttä, E.; Saarela, M.; Mattila-Sandholm, T.; Latva-Kala, K.; Helander, I. Lactic acid permeabilizes gram-negative bacteria by disrupting the outer membrane. Appl. Environ. Microbiol. 2000, 66, 2001-2005. [CrossRef]

44. Charkowski, A.O.; Sarreal, C.Z.; Mandrell, R.E. Wrinkled alfalfa seeds harbor more aerobic bacteria and are more difficult to sanitize than smooth seeds. J. Food Prot. 2001, 64, 1292-1298. [CrossRef]

45. Mujumdar, S.; Bashetti, S.; Pardeshi, S.; Thombre, R.S. Industrial applications of biosurfactants. In Industrial Biotechnology: Sustainable Production and Bioresource Utilization, 1st ed.; Apple Academic Press: Palm Bay, FL, USA, 2016 ; p. 484.

46. Dekkers, L.C.; Bloemendaal, C.J.P.; de Weger, L.A.; Wijffelman, C.A.; Spaink, H.P.; Lugtenberg, B.J. A two-component system plays an important role in the root-colonizing ability of Pseudomonas fluorescens strain WCS365. Mol. Plant-Microbe Interact. 1998, 11, 45-56. [CrossRef] [PubMed] 
47. Aruscavage, D.; Miller, S.A.; Lewis Ivey, M.L.; Lee, K.; LeJeune, J.T. Survival and dissemination of Escherichia coli O157:H7 on physically and biologically damaged lettuce plants. J. Food Prot. 2008, 71, 2384-2388. [CrossRef] [PubMed]

48. Cooley, M.B.; Chao, D.; Mandrell, R.E. Escherichia coli O157:H7 survival and growth on lettuce is altered by the presence of epiphytic bacteria. J. Food Prot. 2006, 69, 2329-2335. [CrossRef] [PubMed]

49. Esseili, M.A.; Chin, A.; Saif, L.; Miller, S.A.; Qu, F.; Lewis Ivey, M.L.; Wang, Q. Postharvest survival of porcine sapovirus, a human norovirus surrogate, on phytopathogen-infected leafy greens. J. Food Prot. 2015, 78, 1472-1480. [CrossRef]

50. Potnis, N.; Soto-Arias, J.P.; Cowles, K.N.; van Bruggen, A.H.; Jones, J.B.; Barak, J.D. Xanthomonas perforans colonization influences Salmonella enterica in the tomato phyllosphere. Appl. Environ. Microbiol. 2014, 80, 3173-3180. [CrossRef]

51. Poza-Carrion, C.; Suslow, T.; Lindow, S. Resident bacteria on leaves enhance survival of immigrant cells of Salmonella enterica. Phytopathology 2013, 103, 341-351. [CrossRef] 